accounts of what to do and exactly how to do it. Perhaps this is' specially so in the final chapter dealing with Resettlement, in which a really excellent account is given of the facilities available and of the way to use them.

The work could hardly have been possible without the facilities provided by the Royal Air Force Medical Service, and it is greatly to the credit of those in charge of that Service that their foresight has made possible this important contribution. The author and his colleagues are to be congratulated on producing a book which is certain to become and remain required reading for all concerned with injuries of the hand in particular and with rehabilitation in general.

\section{LUNG FUNCTION TESTS}

By B. H. Bass, M.D., M.R.C.P. Pp. vii +72 with 17 illustrations. London: H. K. Lewis \& Co. Ltd. I959. 8s. 6d.

This very small book is presented, according to the preface, as an introduction to the principles of clinical pulmonary physiology and is not, as the title rather suggests, a description and critical assessment of lung function tests. It briefly outlines the essential components of normal respiration and indicates how each one can become deranged in disease and how attempts can be made to measure the extent of these derangements. It is very easily readable and must contain much that is new to those who have never studied respiratory diseases previously. However, the subject has been rather over simplified and a more critical approach would have been welcomed. This is especially 80 in the chapter on ventilation where some indices are presented as having an established position in lung function testing whereas they are rarely used in most centres in this country. Another criticism is that there are no references either to further reading in pulmonary physiology or to more detailed descriptions of the performance and limitations of the tests mentioned. These seem important omissions in any book purporting to be "an introduction."

W.B.T.

\section{ELECTROCARDIOGRAPHIC ANALYSIS}

\section{Vol. I}

\section{Biophysical Principles of Electrocardiography}

RoberT "H. BaYley, M.D. Pp. xvi + 237. London: Cassell \& Co. Ltd. 1958. 6os.

The author is an acknowledged leader in the field of electrocardiography and his research has yielded much information about the use of unipolar leads and vector analysis. His aim in this book is to provide an approach to the analysis of electro- cardiographic wave forms through a basic knowledgę of mathematics and electricity. His text is de $z$ veloped from his great experience of teaching a $\mathbb{L}_{2}$ undergraduate and postgraduate levels.

The emphasis is placed on the appreciation of the importance of the electrical axis and vector analysis during atrial and ventricular accession and regres sion of the electrical impulse. There follows a5 discussion of the changes associated with ventriculaw hypertrophy, disease, drugs and injury. There is an explanation of the triaxial reference system using both bipolar and unipolar leads which is of partits cular value in the assessment of the anatomical type of an atrial septal defect and when full vector analysis is not undertaken.

The subject matter of this volume is beyond the scope of the general physican, but will be of value for those developing a specialized knowledge o $B$ electrocardiography.

The value of Volume I as a basis for electro or cardiographic analysis should be confirmed whero Volume II ' Clinical Application of Electrocardio graphy' appears shortly. This will have speciaf reference to congenital heart disease.

\section{OBSTETRICAL PRACTICE}

By Alfred C. Beck, M.D., and Alexander g Rosenthal, M.D. Seventh Edition. Pp. Witi $+I_{1} 1_{5}$, illustrated. London: Baillière, Tind if \& Cox Ltd. I 958 . I i 2 S.

This is the Seventh Edition of the very wet established American book on Obstetric Practice It is, as can be seen, a large book and therefore contains, or should contain, a great deal about the practical details of the art and science of obstetrics $\vec{B}$ It is fully illustrated with many line drawings and $\mathbf{i}$ makes quite clear the mechanisms of most obstetrio deliveries and manoeuvres.

It is a little lop-sided in its writing. For instance. brow presentation receives one scanty page, whereas ectopic pregnancy is dealt with fully from the pathological angle but not really quite adequately from the diagnostic and differential diagnostic angle. The book has an established place in American obstetrics and is a valuable reference book for the specialist obstetrician.

\section{CLINICAL OBSTETRICS AND GYNAECOLOGY, Vol. 1 , No. 3}

\section{옥}

'Abnormal Uterine Bleeding' edited by JoHn BREWER, M.D.; 'Special Diagnostic Aids edited by C. Paul Hodgkinson, M.D. Neq York: Paul B. Hoeber, Inc. 1958.

This is the third section of the first volum presented in book form of the Clinical Obstetrio and Gynaecology series which appears four times year. This number is devoted in the main to 9 
symposium of special diagnostic aids, of which the overall editor is C. Paul Hodgkinson, M.D.

In this section, the more recent and not so recent aids in making gynaecological diagnosis more accurately are described and reviewed.

It starts with a very fair review of the way of staging uterine cancer and inevitably proceeds to discussion of cytology, including more exotic methods of obtaining cytological specimens.

Culdocentesis and culdoscopy have small chapters.

There is an excellent summary of the indications and contraindications and dangers of hystersalpingography and there are also good reviews of the value of $X$-ray pelvimetry and of soft tissue placentography together with a new technique of urethrocystograms.

The diagnosis of toxaemia of pregnancy is treated rather superficially.

The second half of the book is devoted to abnormal uterine bleeding under the editorship of John I. Brewer, M.D. The causes are reviewed and unusual conditions like bleeding in children are written about.

There is a very sensible chapter on menopausal and postmenopausal bleeding and another small one on the psychosomatic aspects of bleeding.

Altogether, this section maintains the high standard set by the previous books in the first year's volume.

\section{EAR, NOSE AND THROAT DYSFUNCTION DUE TO DEFICIENCIES AND IMBALANCES}

By Sam E. Roberts, M.D. Pp. xxiii +305 , with 57 illustrations. Oxford: Blackwell Scientific Publications. 1957. 63s.

The basis of the book's raison d'etre, and a wholly laudable one, is that many disorders in the field of otolaryngology are the localized manifestations of a constitutional disease.

The author has candidly stated that much in the book is founded on clinical observation and the results described are, in part, subjective. These deficiencies and imbalances are nutritional, electrolytic, hormonal, acid base and insulin sugar and the sub-clinical conditions thereof have not been helped and may have been impeded by available laboratory tests.

Many working hypotheses have been used by the author to support his views. The basis of all treatment throughout the book is the therapeutic test and is reinforced by many case reports-these are not wholly convincing. The correction of gonadal imbalance is a constant theme and would appear to contribute to many conditions such as vascular headache, Meniere's Disease, acoustic nerve and sinus dysfunctions.

The author says that he is not expecting total acceptance of his views, even anticipating vehement opposition.

This is a fair assessment.

P.A.

\section{SURGEON AT ARMS}

By Daniel Paul. Pp. 227, with illustrations. London: William Heinemann Ltd. 1958. r6s.

Daniel Paul conceals the identity of an orthopaedic surgeon who as a member of the Parachute Field Ambulance was captured at Arnhem. After many adventures and frustrating delay he managed to escape back to the British line. Most of the story is concerned with his hiding with the Dutch Resistance, and interesting as this is, the Reviewer personally would have liked to hear more about the Arnhem Battle.

However, the book is an exciting story written about a man of obvious courage and determination and should have a wide appeal both to the general public and to doctors, particularly those who have served with Airborne Forces.

D.W.S.G.

\section{PSYCHIATRY IN THE BRITISH ARMY IN THE SECOND WORLD WAR}

By R. H. Ahrenfeldt. Pp. xv + 312. London: Routledge and Kegan Paul Ltd. 1958. 35 s.

The most striking thing about this book is the diversity of function of the army psychiatrist which it describes. Many of the widely disparate duties can only be related to mental hygiene by stretching the imagination, and only two of the ten chapters describe traditional medical work in caring for and treating soldiers with psychiatric disabilities. The remainder of the book records the work of the psychiatrist in such unfamiliar fields as personnel selection, service discipline and morale, training, civil resettlement, and the like. This is not to negate the value of the book; on the contrary, it throws a new light on the contribution which psychiatry made to acute social problems in a time of national emergency, and so fills many of the gaps left by the more conventional medical histories of the war.

Looking back in retrospect and with the comprehensive overview provided by available documents and postwar surveys, much of this work, which was essentially on a trial-and-error basis, was perhaps less important than the author makes out. Few would certainly agree with the author that in officer selection and in the assessment of temperamental factors 'psychology is the handmaid of psychiatry.' The study of behaviour of normal individuals, is of course, Psychology's special province, and readers capable of differentiating these two disciplines will quickly realise that the major function of this book has been to put the case for Military Psychology; it is noteworthy that the psychiatrists who, in the author's opinion, made the most significant contributions to this aspect of service needs were in fact men who were better known in psychological circles than psychiatric ones. Dr. J. D. Sutherland, former President of the British Psychological Society, is perhaps the 